\title{
Student in the Seats, Teacher in the Streets: Evaluating the Impacts of Law Students
}

\section{Becoming "Street Law" Teachers}

Brandon Golob ${ }^{1}$

Abstract

The need for public legal education is at an all-time high. From constitutional law issues raised by the 2020 United States presidential election to increased media coverage of police brutality, there are numerous examples of why it is crucial to teach practical law to non-lawyers. Street Law programs, administered by law students to teenagers, are a prominent type of public legal education. Despite the urgent importance of Street Law programs, there is limited research on their pedagogical effectiveness, or how they affect those who administer them. This project helps to close that gap through its multimethod research on the course instructors. In addition to completing this program evaluation, the project also (1) develops a theoretical framework that will enable law school administrators and scholars from a variety of disciplines to understand how law students are impacted by Street Law programs, and (2) lays the foundation for future assessments of Street Law and other public law education programs. The importance of

\footnotetext{
${ }^{1}$ Assistant Professor of Teaching in Criminology, Law and Society at the University of California, Irvine. I can be reached here. I would like to thank Dr. Sandra Ball-Rokeach, Dr. Alison Trope, Commissioner Laura Cohen, Dr. Katherine Elder, and Skyler Courter for their editorial, methodological, and moral support with this project. I would also like to thank all the Street Law faculty, alumni, and students who participated in my research.
} 
understanding the impacts of these programs, which the results of this study show to be overwhelmingly positive, cannot be overstated because they have broad potential to affect law students' transition to practice and society at large.

Keywords: public legal education, law school, program evaluation, street law, self-efficacy

\section{INTRODUCTION}

In 1972, a small group of law students and professors from Georgetown University Law Center (GULC) piloted a clinical legal education program called "Street Law." Based in two District of Columbia public high schools, the purpose of the program was to educate these teenagers about laws and legal systems that impact their daily lives. Due to the success of GULC's program, a national organisation began to form. Formalised in 1975, the National Institute for Citizen Education in the Law spread the news of the GULC program's successes and sought to help launch similar programs across the nation (Alexander, 1993). Over the last half century, Street Law has grown substantially: there are currently more than 120 iterations of this program at law schools in the United States and beyond (Arbetman, 2018). However, despite the growth of such programs, there has been limited research on them (Arbetman, 2018; Arthurs, 2015; O'Brien, 1977; Pinder, 1988; Roe, 2012). Moreover, research that focuses on the teenagers' learning outcomes 
(Arthurs, 2015) does not account for a crucial aspect of the Street Law programs that distinguishes them from other public legal education programs - namely, that they are also part of law students' training and education. This project helps to close that gap through its multimethod research on the course instructors: law students. The focus of this project is on how their participation in Street Law can impact their law school experience, transition to practice, and subsequent careers. Specifically, it measures how Street Law impacts law students': (1) approaches to learning, and (2) self-efficacy for a variety of lawyering skills.

\section{BACKGROUND}

\section{Program Evaluation of Street Law}

Street Law programs are a type of public legal education programs, institutionalised in law schools and administered to teenagers. Some scholarly assessments of these programs have been undertaken (Arbetman, 2018; Arthurs, 2015 MacDowell, 2008; Montana, 2009; O'Brien, 1977; Pinder, 1988; Roe, 2012), but they are largely descriptive and lack common approaches to program evaluation. Moreover, although some programs have set up internal mechanisms for evaluation on a non-empirical level, most of them have not done this. For example, the GULC program has evaluated its effectiveness by asking law students who completed the course to journal about their 
experiences, and some of the law students claimed that high school students were highly involved and receptive to the legal concepts taught (Pinder, 1988). UCLA Law's program follows a similar practice, requiring law students to submit bi-weekly journals chronicling their experiences teaching in K-12 schools throughout Los Angeles (Tolbert, 2018).

Law Student Instructors

At first blush, it makes sense to focus research on the teenagers' learning outcomes; after all, they are the population that is being served. However, one who dives beneath the surface of analysis discovers that from a higher education perspective, Street Law programs are also intended to benefit the law students who participate in them. Some Street Law literature touches on this point (Kovach, 1998; MacDowell, 2008; Montana, 2009; O'Brien, 1977; Pinder, 1988; Roe, 2012), but does not empirically assess the impacts on law students. Other evaluations analyse programs that train Street Law teachers before they enter the classroom, but do not look at the effects on law students after they have taught (Arthurs et al., 2017).

Moreover, it is important to note that Street Law programs are not administered in a standardised way. A review of Street Law programs across the nation reveals several 
structural, curricular, and population differences. ${ }^{2}$ Thus, this dearth of rigorous evaluation can perhaps be attributed to the fact that evaluation of Street Law may seem unduly complex. However, regardless of the countless differences, there is one constant of all Street Law programs: law student instructors. Thus, this project capitalises on that similarity by conducting a program evaluation that analyses how Street Law programs function in the higher education of law students.

\section{Self-Efficacy in Educational Contexts}

In 1977, social psychologist Albert Bandura developed the construct of self-efficacy as a clinical tool. Simply put, "perceived self-efficacy refers to beliefs in one's capabilities to organize and execute the course of action required to produce given attainments" (Bandura, 1997, p. 3). Such beliefs are critically important because peoples' beliefs in their abilities to achieve certain actions can have widespread and lasting impacts on their aspirations, motivations, performance, and so forth (Bandura, 1997; Bouffard-Bouchard, 1990; Zimmerman, 2000). This project focuses on the theoretical and methodological application of the construct in the education field.

Specific to the education context, self-efficacy has been shown to impact students' interests and goals, choices for majors and other activities, persistence in the face of

\footnotetext{
${ }^{2}$ A review of numerous Street Law programs' syllabi and course descriptions (in addition to conversations with Street Law directors and students from across the nation) revealed the varied nature of Street Law curriculum.
} 
adversity, level of effort exerted, and ultimately, their overall academic achievement (Bandura, 1997; Lent et al., 2008; Multon, Brown, \& Lent, 1991; Pajares, 1996; Schunk, 1995). In short, students with higher self-efficacy achieve at a higher level (Lent, Brown, \& Larkin, 1984; Schunk, 1991). It follows, then, that since self-efficacy has such a large impact on student achievement, education scholars have taken great interest in determining the sources of students' self-efficacy beliefs (Hampton, 1998; Matsui, T., Matsui, K., \& Ohnishi, 1990; Usher \& Pajares, 1998).

Self-Efficacy in Law School

Although the self-efficacy construct has been applied in a myriad of educational contexts (Rosen, Glennie, Dalton, Lennon, \& Bozick, 2010; Usher \& Pajares, 2008), there is a paucity of literature exploring how the construct of self-efficacy may predict achievement outcomes for law students (Christensen, 2009; Diaz, Glass, Arnkoff, \& Tanofsky-Kraff, 2001; McKinney, 2002; Palmer, 2015). Bearing in mind the lack of rigorously methodological instruments for measuring the self-efficacy of law students, there is much room for improved scholarship in this context. Returning to Bandura's (1977) seminal work on self-efficacy and behavior change, he cites an individual's personal mastery as the most important influence on self-efficacy. Thus, this project measures personal mastery as the first dependent variable of interest. 
Many scholars have explored the connection between students' self-efficacy and academic achievement in a variety of contexts (Multon, Brown, \& Lent, 1991; Pajares, 1996; Schunk, 1984). Most germane to this project, some scholars have even studied how the pedagogical structure of law schools need to be reformed to improve law students' self-efficacy (Palmer, 2015; Schwartz, 2003). A pervasive criticism of the pedagogical structure of law schools is that it tends to emphasise performance-oriented learning instead of mastery-oriented learning (Christensen, 2009; Fines, 1996; Palmer, 2015; Schwartz, 2003). Performance orientation means focusing on competition and comparison to others, while mastery orientation means focusing on learning and selfimprovement. However, despite the fact that law school curriculum conditions students to be performance-oriented, previous research has shown that the most successful law students are those who are mastery-oriented learners (Christensen, 2009). Since Street Law programs that are built into the law school curriculum do not follow the traditional, curved grading system and allow students the opportunity to collaborate and learn from one another, they may be a critical breeding ground for developing mastery-oriented goals. Therefore, it is important to determine whether these programs empower students to approach learning from a more mastery-oriented (versus performance-oriented) perspective:

RQ1: Does participation in Street Law impact law students' mastery-oriented goals?

RQ2: Does participation in Street Law impact law students' performance-oriented goals? 
Even beyond academic success, developing mastery-oriented goals has also been shown to help increase a student's self-efficacy (Dweck \& Leggett, 1988; Palmer, 2015). One skill set that is particularly important for law students to believe is within their capacity is communicating legal concepts to non-lawyers; after all, effective client communication is the cornerstone of many legal industries (Cunningham, 1998). Foundational literature on Street Law programs claims that these programs help law students cultivate this skill set because the programs train their students how to communicate complex legal concepts to people not familiar with the legal language - a necessary skill for those who aspire to advocate effectively (Roe, 2012; Pinder, 1988). However, there is only anecdotal evidence (i.e., law student journals collected by certain law schools and course objectives listed in Street Law syllabi) in support of this contention. Thus, this project translates such anecdotal evidence into empirical data by measuring whether participation in Street Law impacts law students' self-efficacy for communicating material to non-lawyers (see Figure 1 below):

RQ3: Does participation in Street Law impact law students' self-efficacy for communicating legal material to non-lawyer audiences? 


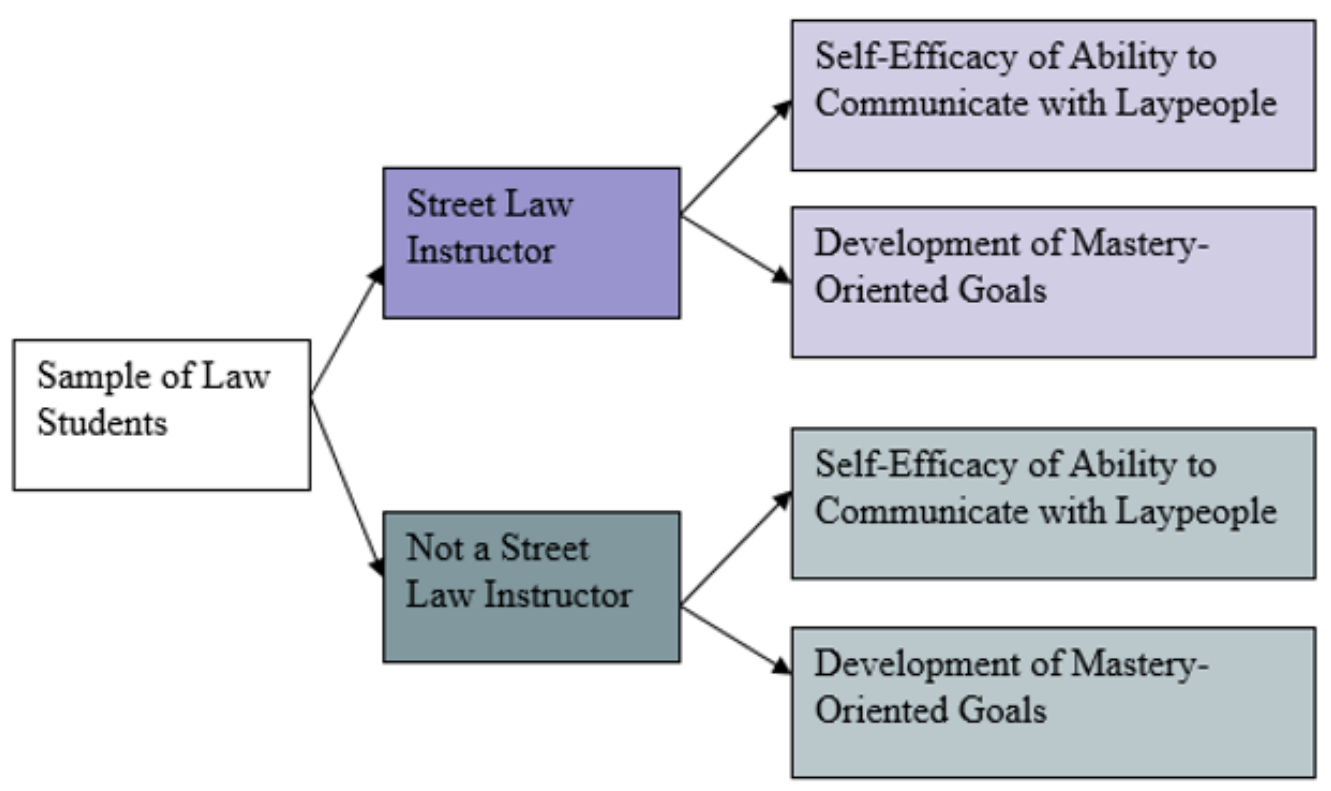

Figure 1 Program Evaluation Research Design

However, translating legal material for non-lawyers is merely one of many competencies that law students are supposed to develop during their legal education. Scholars have identified numerous technical skills that are critical for being a lawyer (Binder, 2003; Boccaccini, Boothby, \& Brodsky, 2002; Maughan \& Webb, 2005; Shultz \& Zedeck, 2011), and a review of Street Law syllabi reveals that the development of many of these skills are often the pedagogical objectives of Street Law programs. Since attempting to measure all the technical skills that are important to lawyering would be unduly burdensome for this project, the focus is placed on one that appears frequently across the literature and is clearly executed in the Street Law context: public speaking. Thus, this project also measures whether participation in Street Law impacts law students' self-efficacy for this skill: 
RQ4: Does participation in Street Law impact law students' self-efficacy for public speaking?

Lastly, it is crucial to acknowledge that scholars have long argued that lawyering effectiveness depends on more than technical competence such as translation of complex legal material and public speaking. Rather, they have found that lawyers who blend technical competence with soft skills (e.g., people skills) are the most effective (Araujo, 1999; Barkai \& Fine, 1982; Smith, 2015; Sternlight \& Robbennolt, 2007). Therefore, this project also measures whether participation in Street Law impacts law students' selfefficacy for soft skills such as developing positive client-relationships:

RQ5: Does participation in Street Law impact law students' self-efficacy for developing lawyer-client relationships?

Granted, measuring some of the most crucial soft skills for lawyers, such as empathy (Barkai \& Fine, 1982; Sternlight \& Robbennolt, 2007), is complex and beyond the scope of this project. Moreover, what specifically constitutes a soft skill is debatable. Thus, the researcher took an inductive approach to this question and relied on interviews, a focus group, and a waiting room survey to assess the soft skills that Street Law participants and alumni contend they develop:

RQ6: Does participation in Street Law impact law students' self-efficacy for developing a variety of soft skills? 


\section{METHOD}

\section{Participants}

Survey

Street Law Inc., the national organisation, keeps a database of active Street Law programs. This database was used for participant recruitment via email. Since it was not possible for the researcher to gain direct access to Street Law instructors in these programs (i.e., the database only lists Street Law program names), the researcher requested that the faculty or student director of each program distribute the survey to the instructors. This also maintained the anonymity of survey respondents. Ultimately, 49 law students completed both the pre-survey and post-survey. Thirty-seven of the respondents were Street Law participants (treatment group), while 12 respondents comprised the comparison group. In total, respondents represented 10 law schools from across the nation: 
Table 1. Street Law Programs Where Respondents Completed Pre-/Post-Survey

\begin{tabular}{|l|l|}
\hline Law School & Number of Respondents \\
\hline Creighton Law School & 7 \\
\hline LSU Paul M. Hebert Law Center & 2 \\
\hline Mitchell Hamline Law School & 3 \\
\hline University of Minnesota Law School & 12 \\
\hline University of St. Thomas Law School & 3 \\
\hline Rutgers School of Law - Camden & 4 \\
\hline Seattle University School of School of Law & 3 \\
\hline Southwestern Law School & 7 \\
\hline UCLA School of Law & 4 \\
\hline Vanderbilt University Law School & 4 \\
\hline
\end{tabular}

In addition to representing different law schools, the respondents' demographic backgrounds varied. In terms of gender identity for the treatment group, $62.2 \%(n=23)$ selected female, $35.1 \%(n=13)$ selected male, a 1.3\% $(n=1)$ selected genderqueer/gender non-conforming. As for the comparison group, $75 \%(n=9)$ selected female, while $25 \%$ $(n=3)$ selected male. In the treatment group, 73\% $(n=27)$ selected White (six of which selected Hispanic or Latino), 2.7\% selected $(n=1)$ selected Asian, 2.7\% $(n=1)$ selected Black or African American, 2.7\% $(n=1)$ selected American Indian or Alaska native, and 18.9\% $(n=7)$ selected Other. As for the comparison group, 75\% $(n=9)$ selected White, 
8.3\% selected $(n=1)$ selected Asian, and 16.7\% $(n=2)$ selected Other. ${ }^{3}$ The mean age for the treatment group was 25.4 years old (with a range of 16 years), while the mean age for the comparison group was 25.5 years old (with a range of 7 years).

\section{Interviews}

Following collection of survey data, the researcher conducted seven semi-structured interviews with respondents who completed the pre-/post-survey. Five of these were indepth interviews with Street Law alumni and two were interviews with law students from the comparison group. Interviews were conducted with individuals who were still enrolled in law school. These respondents were selected because one of the primary purposes of the interviews was to assess more immediate impacts of Street Law participation on individuals continuing to work on their law degree. These interviews can be contrasted with the focus group, which selected law school alumni as participants to assess the long-term impacts of participation in Street Law. In order to represent all of the law schools that participated in this study, one student from each of the 10 law schools that had respondents for both the pre-/post-survey was invited for a follow-up interview.

The participants were also selected because their demographic backgrounds varied. 42.9\% $(n=3)$ selected female, $42.9 \%(n=3)$, selected male, and $14.3 \%(n=1)$ selected

\footnotetext{
${ }^{3}$ This lack of racial and ethnic diversity is reflective of the legal profession as a whole. According to Bureau of Labor Statistics (2020), 83.5\% of all people employed in legal occupations identify as White.
} 
genderqueer/gender non-conforming. In terms of racial and ethnic identity, 85.7\% $(n=6)$ selected White (one of which selected Hispanic or Latino) and 14.3\% $(n=1)$ selected Other. The mean age was 26 years old, with a range of eight years. Lastly, the participants were a nearly even split in their year in law school: $42.9 \%(n=3)$ were first-year law students when they completed the survey, while $57.1 \%(n=4)$ were second-year law students when they completed the survey. It is important to note that all respondents showed a measurable difference in their pre-/post-survey responses and participated in the interview approximately one year after the survey. This timeline was used so that interview data could reflect the respondents' development as law students since first participating in the study.

\section{Focus Group}

A focus group was conducted with nine alumni of the Southwestern Law School Street Law Clinic. The survey and follow-up interviews focused on currently enrolled law students, while the primary purpose of the focus group was to analyse potential longterm impacts of participation in Street Law. The recruited participants help reflect the history of the clinic because their program completion dates span over a decade. In terms of gender identity, $66.7 \%(n=6)$ selected female and $33.7 \%(n=3)$ selected male. In terms of racial and ethnic identity, 44.4\% $(n=4)$ selected White ( 2 of which selected Hispanic or 
Latino), 22.2\% $(n=2)$ selected Black or African American, 22.2\% $(n=2)$ selected Asian, and $11.1 \%(n=1)$ selected Other. The mean age was 34.9 years old, with a range of 12 years. Lastly, the participants represented a wide array of careers: $22.2 \%(n=2)$ work in the private sector; $22.2 \%(n=2)$ work for the government; $22.2 \%(n=2)$ work for nonprofit organisations; 33.3\% $(n=3)$ work in higher education and administration.

\section{Procedures}

Quantitative Data Analysis

The survey included: (1) a questionnaire asking law students about their achievement goals (adapted from Elliot and McGregor, 2001) and (2) a questionnaire measuring law students' self-efficacy for several crucial lawyering skills, such as communicating legal material to non-lawyers (which follows Bandura's (2006) guidelines for constructing selfefficacy scales). These surveys were given twice: (1) at the beginning of the semester, before law students had Street Law teaching experience, and (2) after the law students finished teaching at their respective sites. This pre-test/post-test was also administered to comparison groups who were not participating in the Street Law program.

In total, there were five dependent variables of interest measured by the survey, corresponding to the first five research questions: (1) mastery-oriented goals; (2) performance-oriented goals; (3) self-efficacy for communicating legal material to non- 
lawyers; (4) self-efficacy for public speaking; (5) self-efficacy for developing lawyer-client relations. Dependent variables (1) and (2) were measured by responses to the achievement goal questionnaire. Dependent variables (3), (4), and (5) were measured by responses to the self-efficacy questionnaire. Results of the survey were analysed using paired samples t-tests to assess mean differences between pre-/post-survey responses for each dependent variable of interest. Paired samples t-tests were conducted on: (1) the treatment group to assess mean differences from pre-test to post-test, and (2) the comparison group to assess mean differences between pre-test to post-test. Mean differences between the treatment group and comparison group were then compared to see which group had the greater change score. Independent samples t-tests were also conducted to check if the change scores of the treatment group versus comparison group were significant. All alpha levels were set at $p<.10$ due to the relatively small sample size.

Qualitative Data Analysis

Interviews. Semi-structured interviews were conducted with recent Street Law alumni instructors who completed the pre-/post-survey. The interview protocol built upon questions asked in the survey and took into account additional skills that make lawyers effective (adapted from Shultz \& Zedeck, 2011). The interviews were conducted virtually 
by the researcher. Each interview was approximately 45 minutes and was transcribed from a recording afterwards.

Focus Group. The focus group protocol followed a similar format to the interview one but also included questions about alumni's post-law school experiences. Directly prior to participating in the focus group, participants completed a waiting room survey. The purpose of this waiting room survey was twofold: (1) to allow participants (especially those who had completed Street Law several years prior) the opportunity to begin remembering and reflecting on their Street Law experiences; and (2) to serve as a check against groupthink, which may occur during focus groups (MacDougall \& Baum, 1997). Thus, the waiting room survey included some similar questions to those asked during the focus group (e.g., What skills did you develop through your work with the Street Law Clinic?) to check for consistency.

\section{RESULTS}

\section{Mastery-Oriented versus Performance-Oriented}

To address the first two research questions (RQ1: Does participation in Street Law impact law students' mastery-oriented goals? and RQ2: Does participation in Street Law impact law students' performance-oriented goals?), results of the survey were analysed using paired t- 
tests to assess mean differences between pre-/post-survey responses for the dependent variables of interest. These variables were: (1) mastery-oriented goals (RQ1; measured by a composite variable created from the six mastery-oriented items in the achievement goal questionnaire); (2) performance-oriented goals (RQ1; measured by a composite variable created from the six performance-oriented items in the achievement goal questionnaire). The results of these tests, for both the treatment group (Street Law students) and comparison group (non-Street Law students) were not significant.

Granted, this binary framework that defines law students as either mastery-oriented or performance-oriented may be limited for measuring how Street Law impacts their approach to legal education. In fact, interviews with Street Law alumni still in law school and Street Law alumni at various stages of their careers revealed that program participation affected the way they learn in complex, difficult to measure ways. Thus, a general inductive approach was taken to condense raw data from these interviews and allow for new themes that describe the ways law students learn to emerge. Throughout these conversations about learning, four subthemes emerged about how Street Law participation can reshape law students' approaches to learning: (1) Street Law improves law students' retention of legal material; (2) Street Law provides law students with practical lawyering experiences; (3) Street Law reminds law students that learning is enjoyable; and (4) Street Law helps law students redefine success in academic and professional environments. 
Retention of Legal Material

Several individual interviewees and focus group members contended that participation in Street Law helped them retain legal material. Specifically, they contrasted their experiences with Street Law against other law school experiences and classes to explain why mastering material was necessary in Street Law. For example, one law student stated that prior to Street Law, she "was not retaining information. It was not learning. It was just like memorizing for the exam and then it was out the window." However, "once Street Law came along...it was very apparent that explaining to someone that is not in law school...was much better and I retain things better than if I studied with my law school buddies." Arguably most importantly, she concluded this point by stating "so that's what I do now. ... That's something I got from Street Law 'cause I don't think I would have tried that otherwise" (Southwestern Law student, personal communication, March 18, 2018). Thus, Street Law helped this student discover a method for mastering law school material (i.e., teaching the concepts to a non-lawyer), which no other law school class or opportunity would have provided. Law school alumni confirmed this point by current students that most classes are about "just keeping [information] in my brain for that few months and then spit[ting] it out on the test." Conversely, "Street Law was more consuming the material, feeling it" (Southwestern Law 2011 alumnus, personal communication, February 12, 2018). In short, Street Law was continually described as a 
singular space in the law school environment - a space where the importance of mastering material, in lieu of simply learning it to perform well on an exam, became clear.

Practical Lawyering Experiences

Related to retention, Street Law participants emphasised that having opportunities to apply the material they learn in practical contexts motivates them to master the legal concepts. Again, alumni focused on how Street Law is different from other experiences and classes in law school because it provides "that practical lens to look at things through" (Southwestern Law 2013 alumnus, personal communication, February 12, 2018). This practical component came from being able to share what one learns in law school outside that academic environment:

In Street Law it really was more practical. You know, things that make sense in the real world that you're going to use and that you can teach to other people. I don't think I've ever had the opportunity to teach what I've learned in my other classes to anyone. (Southwestern Law 2011, personal communication, February 12, 2018)

Some alumni extended this point by connecting Street Law experiences to their current careers. According to one alumnus who practices as a constitutional lawyer, "Doing Street Law helped me see 'oh, I'm gonna learn constitutional law really well so that I could later advocate for my client'" (Southwestern Law 2008 alumnus, personal 
communication, February 12, 2018). Of particular note is this alumnus' comment as to how Street Law made her want to learn the material from other law school classes (i.e., constitutional law). Importantly, the goal for learning was not performance-oriented (i.e., to do well on an exam), but rather, mastery-oriented (i.e., learn that material really well in order to be able to retain it and advocate for future clients). A UCLA Law student made explicit this connection between participation in Street Law and decreased concern with performance in individual classes:

There's like this practicality that comes from Street Law that you don't get through any of law school... It really doesn't matter if you got an A in contracts, like can you figure out... when you're reading a contract [if it sounds] right... Is your client gonna understand why their firing was [or was not] chill? Can you help them figure that out?... (UCLA School of Law student, personal communication, March $16,2018)$

However, although Street Law helped students see the importance of thinking beyond grades, that did not mean their academic performance suffered. In fact, many law school alumni contended that they believe Street Law had a positive impact on their performance. According to one alumnus during the focus group, who several other participants agreed with, when "I think about looking at my GPA, before Street Law and after Street Law, it kind of went up a bit. Because now I see, 'well ok this is where all this 
is going'... and I really loved it" (Southwestern Law 2013 alumnus, personal communication, February 12, 2018).

\section{Learning is Enjoyable}

Law students across the nation stressed that participating in Street Law helped them rediscover what they like about learning in general, and specifically in the law school context. One Seattle University law student explained how "a lot of times [in law school] you're just focusing on what's important to like learn for the course" but "Street Law makes you think a little bit more like what's interesting to you" as an individual. This student argued that this self-discovery process is wrapped up in the act of teaching:

When you have to actually sit down and think to yourself, "Okay, well what do I find really interesting about the law? What would I want to share with somebody else? What do I think that they have to know to be a good citizen?" When you start asking yourself those questions, I guess you start reaffirming to yourself what you find interesting in the law. (Seattle University School of Law student, personal communication, March 16, 2018)

Students also emphasised that Street Law offered a refuge from the typical, performanceoriented approach to learning in law school. As one University of Minnesota law student stated, the "first year of law school is very competitive" but Street Law was different 
"because we were working with a team. We got a partner. We were all working towards the same goal. It's fun talking with students, it's fun helping clients" (University of Minnesota Law School student, personal communication, March 13, 2018). A law student at Mitchell Hamline took this point a step further, stating that it is not only first year that is competitive, but that legal education in general forces students to constantly compare themselves to their colleagues:

When you interact with youth it reminds you how fun it is to learn, especially when something is new. Like it's important to be a civically engaged person and feel like someone who has efficacy. So, I think interacting with people who get genuinely excited about it helps remind me like "oh yeah, you also fundamentally are like that and it's unfortunate that you're being compared," but that's what you are doing for three years. (Mitchell Hamline School of Law student, personal communication, March 16, 2018)

Thus, the law school environment often breeds a competitive environment that stifles students' enjoyment for learning (Dolovich, 1998). Street Law, on the other hand, is seen as an antithesis of this performance-obsessed approach to learning and can renew student interest in legal material. 


\section{Redefine Success}

Related to decreasing students' performance-oriented approach to learning, Street Law alumni asserted that their participation in the program helped them redefine what success in law school meant for them. As one law student said, "I think the first year coming into law school, I was completely obsessed with [performance]. My goal was to be like top ten percent" but "come Street Law, it was the whole teaching students thing that changed it for me." While her original goal was to focus on class performance, "Street Law put that pause for me or slowed me down if you will... It just kind of made me reflect on what it is that I really want to do." Ultimately, her new definition of success is "end[ing] up somewhere where I really want to be rather than having that thought that I did before like 'oh I just want to make money and not be happy'" (Southwestern Law student, personal communication, March 18, 2018). Other Street Law alumni echoed this point about changing their notions of success, but were more explicit about how their experiences as teachers is what moved them away from a performance-oriented approach to learning. Several interviewees mentioned that it was the act of "failing" in front of their students (e.g., having a lesson that did not engage students) that made them redefine success. As one alumni described it, the law school "system is set up in a way that you are seeking the A by somebody else," but Street Law was different because you do not get assessed by some objective measure. Rather, as this interviewee said, each new Street Law teaching session created a "challenge for me to try and figure out what success will 
mean in this scenario." In short, "the experience of failure helps you redefine success" because it forces you to "find what your own A looks like" (Southwestern Law 2017 alumnus, personal communication, February 12, 2018).

\section{Self-Efficacy}

To address research questions three, four, and five (which all tied to self-efficacy for technical lawyering skills), results of the survey were analysed using paired t-tests to assess mean differences between pre-/post-survey responses for the dependent variables of interest. These variables were: (1) communicating legal material to non-lawyers (RQ3; measured by items 1, 5); (2) public speaking (RQ4; measured by items 3, 8); (3) developing lawyer-client relationships (RQ5; measured by items $2,4,67,9,10){ }^{4}$ The results of these tests, for both the treatment group (Street Law students) and comparison group (nonStreet Law students) are reported below:

\footnotetext{
${ }^{4}$ The dependent variable of developing lawyer-client relationships was measured through more items than the other self-efficacy variables were. This is because lawyer-client relationships are multifaceted and can thus be analysed several ways. See RQ5 results below for further explanation.
} 
Table 2 Paired Samples T-Tests for Treatment Group's Self-Efficacy Variables

\begin{tabular}{|c|c|c|c|c|c|}
\hline Variable & Mean & $\begin{array}{l}\text { Standard } \\
\text { Deviation }\end{array}$ & $\mathrm{t}$ & $\mathrm{df}$ & Sig. (2-tailed) \\
\hline $\begin{array}{l}\text { Item 1: Explain legal concept to } \\
\text { non-lawyer }\end{array}$ & -.51 & 1.17 & -2.67 & 36 & $.011^{* *}$ \\
\hline $\begin{array}{l}\text { Item 2: Develop positive } \\
\text { relationship with clients }\end{array}$ & -.24 & 1.34 & -1.10 & 36 & .277 \\
\hline $\begin{array}{l}\text { Item 3: Speak to small group of } \\
\text { non-lawyers }\end{array}$ & -.27 & 1.09 & -.15 & 36 & .881 \\
\hline $\begin{array}{l}\text { Item 4: Think on feet while } \\
\text { communicating with clients }\end{array}$ & .08 & 1.14 & .43 & 36 & .668 \\
\hline $\begin{array}{l}\text { Item 5: Teach non-lawyers } \\
\text { about their rights }\end{array}$ & -.30 & 1.27 & -1.43 & 36 & .162 \\
\hline $\begin{array}{l}\text { Item 6: Adapt to an unexpected } \\
\text { occurrence with clients }\end{array}$ & .00 & 1.45 & .00 & 36 & 1.000 \\
\hline $\begin{array}{lrl}\text { Item 7: } & \text { Develop } & \text { positive } \\
\text { relationship } & \text { with } & \text { difficult } \\
\text { clients } & & \end{array}$ & -.38 & 1.36 & -1.70 & 36 & $.100^{*}$ \\
\hline $\begin{array}{l}\text { Item 8: Speak to larger group of } \\
\text { non-lawyers }\end{array}$ & -.17 & 1.32 & -.76 & 35 & .454 \\
\hline $\begin{array}{l}\text { Item 9: Describe your role as } \\
\text { lawyer/advocate to clients }\end{array}$ & -.54 & 1.68 & -1.96 & 36 & $.058^{*}$ \\
\hline $\begin{array}{l}\text { Item 10: Continue to work with } \\
\text { clients after disruptive } \\
\text { experience }\end{array}$ & -.16 & 1.37 & -.72 & 36 & .474 \\
\hline
\end{tabular}


Table 3 Paired Samples T-Tests for Comparison Group's Self-Efficacy Variables

\begin{tabular}{|c|c|c|c|c|c|}
\hline Variable & Mean & $\begin{array}{l}\text { Standard } \\
\text { Deviation }\end{array}$ & $\mathrm{t}$ & $\mathrm{df}$ & Sig. (2-tailed) \\
\hline $\begin{array}{l}\text { Item 1: Explain legal concept to } \\
\text { non-lawyer }\end{array}$ & .083 & 1.38 & -.21 & 11 & .838 \\
\hline $\begin{array}{l}\text { Item 2: Develop positive } \\
\text { relationship with clients }\end{array}$ & -.25 & 1.55 & -.56 & 11 & .586 \\
\hline $\begin{array}{l}\text { Item 3: Speak to small group of } \\
\text { non-lawyers }\end{array}$ & -.33 & 1.61 & -.72 & 11 & .489 \\
\hline $\begin{array}{l}\text { Item 4: Think on feet while } \\
\text { communicating with clients }\end{array}$ & -.33 & 2.10 & -.55 & 11 & .594 \\
\hline $\begin{array}{l}\text { Item 5: Teach non-lawyers } \\
\text { about their rights }\end{array}$ & -.08 & 1.56 & -.19 & 11 & .857 \\
\hline $\begin{array}{l}\text { Item 6: Adapt to an unexpected } \\
\text { occurrence with clients }\end{array}$ & .17 & 1.64 & .35 & 11 & .732 \\
\hline $\begin{array}{lrl}\text { Item 7: } & \text { Develop } & \text { positive } \\
\text { relationship } & \text { with } & \text { difficult } \\
\text { clients } & & \end{array}$ & -.33 & 1.37 & -.84 & 11 & .417 \\
\hline $\begin{array}{l}\text { Item 8: Speak to larger group of } \\
\text { non-lawyers }\end{array}$ & -1.08 & 2.31 & -1.62 & 11 & .133 \\
\hline $\begin{array}{l}\text { Item 9: Describe your role as } \\
\text { lawyer/advocate to clients }\end{array}$ & -.67 & 1.72 & -1.34 & 11 & .207 \\
\hline $\begin{array}{l}\text { Item 10: Continue to work with } \\
\text { clients after disruptive } \\
\text { experience }\end{array}$ & -.58 & 1.51 & -1.34 & 11 & .206 \\
\hline
\end{tabular}


The comparison group did not show a significant increase for any of the items. However, the treatment group did show a significant increase for items 1, 7, 10, which measure the following dependent variables of interest: (1) communicating legal materials to nonlawyers (item 1), and (2) developing lawyer-client relationships (items 7, 10). These survey results are discussed in further detail below, along with qualitative data results.

\section{Communicating Legal Material to Non-Lawyers}

To address the third research question (Does participation in Street Law impact law students' self-efficacy for communicating legal material to non-lawyer audiences?), results of the survey were analysed using a paired t-test to assess mean differences between pre-/post-survey responses for the dependent variable of communicating legal material to non-lawyers. To measure this dependent variable, respondents were asked: "How confident are you that you can explain a legal concept to a non-lawyer, regardless of their familiarity with the topic?" (Item 1). ${ }^{5}$ There was a significant increase in this confidence level for the law students after participation in Street Law $(M=7.84 ; S D=1.39)$ when compared with before they taught $(M=7.32 ; S D=1.31) ; t(36)=2.67 ; p=.011)$. Conversely, there was not a significant increase in the confidence level for the law students who did not participate

\footnotetext{
${ }^{5}$ Respondents were also asked, "How confident are you that you can teach non-lawyers about their rights, regardless of their familiarity with those rights?" (Item 5). Although results for this item were not significant (see Table 2), Street Law participants showed a nominal average increase in confidence for this skill between pre-test $(M=7.59 ; S D=1.59)$ and post-test $(M=7.89 ; S D=1.35)$.
} 
in Street Law at the post-test $(M=8.33 ; S D=1.30)$ compared with the pre-test $(M=8.42$; $S D=1.56) ; t(11)=.209 ; p=.838)$. Thus, Street Law students showed an increase in confidence for explaining a legal concept to non-lawyers after teaching their classes, while the comparison group did not show a positive change during the same time period. Consistent with these results, Street Law alumni that were interviewed individually and in a focus group setting cited communicating legal material to non-lawyers as the skill they most developed through participation in Street Law. During interviews, several individuals contrasted Street Law with traditional law school experiences to describe how the law school setting rarely gives you the opportunity to learn how to explain legal material to non-lawyers. As one Seattle University School of Law student explained,

When you just use the concepts in school with other lawyers, you know law students and lawyers, you kind of take for granted certain pieces of these concepts and [in Street Law] you have to actually break them down and pull them apart to see how the best way to explain it is. I think that kind of made me feel more confident in taking some of these law school concepts or legal concepts and breaking those down a little bit in more simple terms. (Seattle University School of Law student, personal communication, March 16, 2018)

Law school alumni contended that this ability to speak to lawyers and non-lawyers differently is integral to professional success. One 2011 alumnus of the Southwestern 
Street Law Clinic explained how at her current job as an employment defense attorney, the firm has all these "brilliant attorneys but... no one's gonna understand what they're saying unless you're an attorney." This made her reflect on the benefits of her Street Law experiences, which "helped [her] learn how to kind of talk to lay people or children about law and try to explain it to them" (Southwestern Law alumnus, personal communication, February 12, 2018).

Although the respondents utilised different language, this core theme of learning how to communicate "in more simple terms" with non-lawyers arose consistently throughout interviews. Time and again, interviewees contended that Street Law taught them how to: (1) "tone things down" (Southwestern Law student, personal communication, March 18, 2018); "just boil it down to a couple key points that they can take back and remember and like make useful at some point" (UCLA School of Law student, personal communication, March 16, 2018); "get right to the point" by thinking "what do these people care about, and how can I make it as clear as possible" (University of Minnesota Law School student, personal communication, March 13, 2018).

\section{Public Speaking}

To address the fourth research question (Does participation in Street Law impact law students' self-efficacy for public speaking?), results of the survey were analysed using a 
paired t-test to assess mean differences between pre-/post-survey responses for the dependent variable of public speaking. To measure this dependent variable, respondents were asked: "How confident are you that you can speak to a small group of non-lawyers (5-10 people)?" (Item 3), and "How confident are you that you can speak to a larger group of non-lawyers (more than 10 people)?" (Item 8). Although the results were not significant (see Table 2 above), Street Law participants did show a nominal average increase in confidence for public speaking. This increase can be seen between pre-test ( $M$ $=8.35 ; S D=1.34)$ and post-test $(M=8.38 ; S D=1.34)$ for confidence speaking in front of small groups, as well as between pre-test $(M=7.89 ; S D=1.41)$ and post-test $(M=8.06 ; S D$ $=1.59)$ for confidence speaking in front of larger groups.

Granted, closed-ended questions on a survey may not be the ideal item format for measuring respondents' confidence for a complex skill like public speaking. In fact, when Street Law alumni were asked the open-ended question of "What skills did you develop through your work with the Street Law Clinic?" in a waiting room survey, half $(n=4)$ of respondents specifically identified public speaking/oral presentation. Moreover, during the focus group, several alumni expanded upon how Street Law was their primary opportunity for developing public speaking skills during their legal training. According to a 2007 alumnus of the Southwestern Street Law Clinic, "Street Law was sort of the first segue for me where I felt like I can be a confident speaker and I can communicate an idea and people will listen to me. So that really helped [my] confidence" (Southwestern Law 
alumnus, personal communication, February 12, 2018). This contention that Street Law was the foundational space for becoming a more confident public speaker was echoed by not only alumni, but also current law students across the nation. One student pointed out that Street Law helped him "improve [his] public speaking skills and there's not a huge opportunity to do that in law school" (University of Minnesota Law School student, personal communication, March 13, 2018).

Through interviews with both law school alumni and law students, it was clear that their increased confidence in public speaking had application beyond the Street Law program. Two distinct contexts arose where Street Law alumni frequently apply their public speaking skills: (1) in other law school classrooms, and (2) in professional settings. In terms of context one, law school classes are often driven by student participation (Madison III, 2007). Thus, developing the ability to speak confidently in front of your colleagues is a necessary part of integrating into the law school environment. Law students at several schools cited Street Law as the reason they feel comfortable voicing their opinions in other classes as well. One student mentioned how before Street Law "[I] rarely if ever voluntarily raised my hand" in class (Mitchell Hamline School of Law student, personal communication, March 16, 2018), while another explicitly stated that because of Street Law "I feel a lot more confident just like speaking about whatever topic we're talking about in class" (UCLA School of Law student, personal communication, March 16, 2018). 
In terms of context two, law school alumni expressed how they continue to use the public speaking/oral presentation skills that they developed in Street Law in their current careers. Importantly, the alumni interviewed represented a wide range of careers, including the private sector, the government, and nonprofit organisations. Thus, public speaking skills were described as critical for a variety of professional fields. An alumnus of the Southwestern Street Law Clinic, who works for the Office of the Los Angeles County Counsel, explained how she still uses skills she developed during Street Law:

I work with a lot of non-lawyers and ... I use those skills for presenting big projects, and [explaining] what the purpose is and what the goal is, and keeping these folks all engaged. You know I use those skills now and I'm sure I would have gotten there eventually but I think that [Street Law] really forced me to do it and I don't know if I would have been forced to do it until I took on this job essentially. (Southwestern Law 2008 alumnus, personal communication, February 12, 2018)

Developing Lawyer-Client Relationships

To address the fifth research question (Does participation in Street Law impact law students' self-efficacy for developing lawyer-client relationships?), results of the survey were analysed using a paired t-test to assess mean differences between pre-/post-survey responses for the dependent variable of developing lawyer-client relationships. To measure this 
dependent variable, respondents were asked: "How confident are you that you can describe your role as an advocate/lawyer to clients?" (Item 9) and "How confident are you that you can develop a positive relationship with the most difficult clients?" (Item 7). ${ }^{6}$ In terms of describing their role, there was a significant increase in this confidence level for the law students after participation in Street Law $(M=8.35 ; S D=1.32)$ when compared with before they taught $(M=7.81 ; S D=1.54) ; t(36)=1.96 ; p=.058)$. Conversely, there was not a significant increase in the confidence level for the law students who did not participate in Street Law at the post-test $(M=8.50 ; S D=1.51)$ compared with the pretest $(M=7.83 ; S D=1.85) ; t(11)=1.34 ; p=.207)$.

Similarly, in terms of developing a positive relationship, there was a significant increase in this confidence level for the law students after participation in Street Law $(M=8.14$; $S D=1.64)$ when compared with before they taught $(M=7.76 ; S D=1.52) ; t(36)=1.69 ; p=$ .100). Conversely, there was not a significant increase in the confidence level for the law students who did not participate in Street Law at the post-test $(M=8.33 ; S D=1.44)$ compared with the pre-test $(M=8.00 ; S D=1.65) ; t(11)=0.842 ; p=.417)$. Thus, Street Law students showed an increase in confidence for developing lawyer-client relationships

\footnotetext{
${ }^{6}$ Respondents were also asked, "How confident are you that you can teach non-lawyers about their rights, regardless of their familiarity with those rights?" (Item 5). Although results for this item were not significant (see Table 2), Street Law participants showed a nominal average increase in confidence for this skill between pre-test $(M=7.59 ; S D=1.59)$ and post-test $(M=7.89 ; S D=1.35)$. Additional items showed no relevant results.
} 
after teaching their classes, while the comparison group did not show a significant change during the same time period.

Consistent with, and expanding upon, these results, Street Law alumni interviewed individually and in a focus group setting highlighted how participating in Street Law increased their confidence for developing lawyer-client relationships. In fact, one interviewee even directly asserted before the focus group began that Street Law is where she "learned how to connect with my clients [that she has] now" (Southwestern Law 2014 alumnus, waiting room survey, February 12, 2018). Throughout these interviews, three key subthemes that emerged were: (1) Learning how to engage Street Law teenagers in the classroom is a skill that directly translates to engaging clients; (2) Street Law trains law students to bridge the professional divide between them and non-lawyers; (3) Street Law prepares law students to interact with diverse client populations.

Directly Translates to Engaging Clients. In terms of subtheme one, a law school alumnus who works as an employment defense attorney explained the connection between engaging Street Law teenagers and engaging clients:

So in Street Law, first of all you gotta get the kid engaged. You got to get them to like pay attention to you and then once you get them to pay attention you have to feed them the information in a way they're gonna understand. Similarly, with your 
client, you have to get them to understand the information or you're gonna go nowhere. (Southwestern Law 2011 alumnus, personal communication, February $12,2018)$

Numerous focus group participants echoed this sentiment, arguing that they were constantly figuring out "how we were going to keep the kids engaged" (Southwestern Law 2008 alumnus, personal communication, February 12, 2018) and how to "really engage and talk with them....and I think that's like probably one of the best skills you can get" (Southwestern Law 2017 alumnus, personal communication, February 12, 2018). In short, law school alumni expressed a clear connection between the skills they developed to engage Street Law teenagers and the skills they currently use to engage clients.

Bridge the Professional Divide. In terms of subtheme two, law students from a variety of schools noted that Street Law was critical in helping them bridge the professional divide between them and non-lawyers. A UCLA Law student explained how she had trouble connecting with her Street Law teenagers at first, but through the program, she learned to "knock off most of the formalism and just be like a normal person who's helping [them] learn about the law" (UCLA School of Law student, personal communication, March 16, 2018). Similarly, a Mitchell Hamline Law student explained how legal concepts and terminology are often "a little bit pretentious" and she needed to 
deformalise the conversations in order to "feel more comfortable" working with students and clients. For example, during one lecture on pro se legal representation, students remarked, "that's just made up language to say that you represent yourself" and she used this as an opportunity to have socioeconomic "class conversations...about the law" (Mitchell Hamline School of Law student, personal communication, March 16, 2018). As one Seattle University law student stated so simply, Street Law taught him how to not only "talk about the law stuff" but also how to "make small talk and just be friendly" with non-lawyers (Seattle University School of Law student, personal communication, March 16, 2018).

Diverse Client Populations. In terms of subtheme three, law students who participated in Street Law noted how the program was a unique opportunity to interact with diverse populations. As one interviewee made explicit, Street Law trained him "how to approach dealing with diverse populations" that are "different than law school [populations]" (University of Minnesota Law School student, personal communication, March 13, 2018). This exposure to different populations is important because as this interviewee suggested, his law school colleagues are not demographically diverse - a point that is in line with the fact that the legal profession has a lack of racial and ethnic diversity (see footnote 2). Thus, without programs such as Street Law, law students would be more limited in their opportunities to discuss legal concepts with a diversity of populations. 
Some Street Law alumni were more specific about the benefits of teaching to diverse populations. For example, one interviewee explained that having "a pretty diverse class" that was "not shy about getting into some political discussions" helped him learn how to "wade through those different issues [and] different viewpoints." He ultimately concluded that it made him more confident about his future interactions with clients because "if you can manage that with like ten different people and different mindsets than it's a little easier when you have maybe a smaller group in front of you" or even a "one-on-one client meeting" (Seattle University School of Law student, personal communication, March 16, 2018). Lastly, alumni credited Street Law with not only giving them the opportunity to interact with diverse populations, but also teaching them to pay attention to the differences within these populations. As one interviewee explained, participating in Street Law "provided nuance to the community which there always was and I just didn't know... And [it showed] how important it is to get the diverse perspectives of a group that you might lump together" (Mitchell Hamline School of Law student, personal communication, March 16, 2018).

Developing Soft Skills

To address the sixth research question (Does participation in Street Law impact law students' self-efficacy for developing a variety of soft skills?), I took an inductive approach that relied 
on (1) semi-structured interviews with law students from across the nation, and (2) a focus group and waiting room survey with Street Law alumni. The most commonly identified soft skills that emerged were: (1) Able to see the world through the eyes of others; (2) Community involvement and service; (3) Listening.

Able to See the World through the Eyes of Others. Shultz and Zedeck (2011) identify wanting to understand other people's views and experiences as a central factor for effective lawyering. Throughout my interviews with Street Law alumni, this is the soft skill that they mentioned most frequently when discussing how the program impacted them. As one 2007 alumnus of Southwestern Law explained, Street Law "was so eyeopening to me - how little I know and how little I can appreciate about other people's experiences... And so it made me much more empathetic and it's forced me to look at life with eyes wide open" (Southwestern Law 2007 alumnus, personal communication, February 12, 2018).

Others categorised this quality as "empathy," but expressed a similar sentiment. Another Street Law alumni from Southwestern, who participated in the program a decade after the previous interviewee, stated that Street Law is a reminder that when interacting with non-lawyers of any age, "what you need to be is human. So I think one of the qualities teaching brings back to you is empathy and building empathy. Something that the world 
seems to be lacking nowadays" (Southwestern Law 2017 alumnus, personal communication, February 12, 2018). Importantly, alumni also explained how they have applied this skill that they learned in Street Law to their current careers. According to one alumni who works for the Office of the Los Angeles County Counsel, Street Law "helped me realize on a very granular level the needs of this underserved population" (Southwestern Law 2008 alumnus, waiting room survey, February 12, 2018):

I grew up knowing that I had rights. I grew up knowing that I could challenge the system right. And so much of this juvenile community, they didn't realize that... Forwarding into what I do now, [Street Law] really helped me to see both sides. I'm very kind of centrist viewpoints on a lot of things and...learning the granular aspects of what this population does know makes me rethink the decisions that I make currently because I work with a [similar] underserved population. (Southwestern Law 2008 alumnus, personal communication, February 12, 2018)

Community Involvement and Service. Shultz and Zedeck (2011) also discuss applying one's legal training and skills to community issues as another critical lawyering effectiveness factor. With regards to this factor, Street Law is an important program because it gives law students an opportunity to begin using their legal skills to benefit their local communities. Several interviewees highlighted how being involved with Street 
Law was a meaningful way to bridge the academy-community divide. As one law student, who worked in after-school programming prior to entering the legal academy, expressed, "When I heard about Street Law, at that point I was like feeling really irrelevant in the ivory tower. I was missing having that day-to-day interaction with youth." She went on to explain how participating in Street Law was the perfect balance between an activity that was "self-interested" but also an opportunity "to feel like I was doing something" for others (Mitchell Hamline School of Law student, personal communication, March 16, 2018). However, even beyond the initial opportunity to connect with local communities that Street Law creates, numerous Street Law alumni contended that the program made them want to serve their communities in other ways both during law school and after graduation. A University of Minnesota Street Law student contended that "Street Law definitely made me continue to care about those issues and continue to care about people who need access to the legal system that, you know, may not readily have it as easily as others." In short, "it made me want to continue to do pro bono work for sure in some capacity... in law school and then afterwards as well" (University of Minnesota Law School student, personal communication, March 13, 2018). Of particular note is that even for students who intended to pursue jobs in the private sector, Street Law cultivated in them a desire to engage in pro bono and public service work whenever possible. Some of the law students expressed a desire to continue working with a population similar to the youth they served through Street Law. As one 
UCLA Law student who has committed to work at a private firm after graduation explained, "I could definitely see myself wanting to work with that particular community again which I hadn't expected... Kids in school are an important point that we're missing in the legal profession. We don't work with them and maybe we should" (UCLA School of Law student, personal communication, March 16, 2018).

Law school alumni who currently work in a variety of legal careers echoed the perspective that Street Law developed their desire, as well as their ability, to apply their legal skills to community issues. As one alumnus who works with underserved populations reflected, "Street Law, you know, reminded me of like what my little, you know, five minutes did with this kid" before ultimately concluding that "it makes me want to continue to give back to this population" (Southwestern Law 2008 alumnus, personal communication, February 12, 2018). However, even those alumni whose careers are in the private sector and do not directly relate to any public service work, still felt that their professional choices have been shaped by Street Law. According to one alumnus who runs his own estate planning and personal injury firm, "I always give back no matter what... I always want to have that one person who I can help... and for me that's just kind of something that I picked up from Street Law" (Southwestern Law 2013 alumnus, personal communication, February 12, 2018). Perhaps one alumnus said it best when he simply remarked that Street Law makes it so you are "always looking for a way that you can help other people" (Southwestern Law 2010 alumnus, personal communication, 
February 12, 2018), or in the words of a law student, "Street Law just makes me want to help out" (Seattle University School of Law student, personal communication, March 16, 2018).

Listening. Shultz and Zedeck (2011) also emphasise that effective lawyers have the ability to correctly perceive what others are saying, which requires active listening. Street Law alumni emphasised that in order to become successful teachers they had to listen to their students' opinions and experiences, and incorporate those into their pedagogy. As a Seattle University law student explained, he learned through Street Law to "try not to lecture for too long" and instead build in time for students to "tell me about themselves in a way that was connected to the material. Just because I felt like in that way they were able to tell a little bit about their own personal life and personal experience" (Seattle University School of Law student, personal communication, March 16, 2018). For many alumni, they have translated this experience of "getting them involved in the conversation" to their current work with clients by "talking with them, instead of talking at them" (Southwestern Law 2011 alumnus, personal communication, February 12, 2018). One alumnus noted how time is limited during client meetings, but "you're gonna listen to them" if you want to "build a relationship" (Southwestern Law 2008 alumnus, personal communication, February 12, 2018). 
Thus, alumni established a clear connection between the importance of listening and developing positive relationships with students and clients alike. Most poignantly, an interviewee extended this point about relationship-building by asserting that the byproduct is a mutually beneficial relationship through which both parties learn:

The question [each class] was like, "What do I have to offer that is different from just repeating what you already know?" I think that part of the learning is that you are as much a student as they are, and it's like a two-way process where you teach and you're getting a learning experience also unique for yourself. (Southwestern Law 2017 alumnus, personal communication, February 12, 2018)

Notably, this interviewee made an effort to emphasise that this two-way process of being both a teacher and student is not limited to the classroom setting. Rather, it is "something that if you can really grasp...you can take it anywhere" (Southwestern Law 2017 alumnus, personal communication, February 12, 2018).

\section{DISCUSSION}

Programs that improve a law students' self-efficacy are a crucial part of higher education. In addition to the ways that self-efficacy may impact a law students' academic performance and transition to practice, a law student instructor's self-efficacy in teaching in Street Law programs will also likely impact student outcomes in the classrooms in 
which those law students teach. After all, education research has demonstrated extensively that a teacher's level of self-efficacy is related to student outcomes, such as achievement and motivation (Armor et al., 1976; Ashton \& Webb, 1986; Protheroe, 2008; Tschannen-Moran, Hoy, A.W., \& Hoy, W.K., 1998). Thus, developing an understanding of Street Law instructors' self-efficacy is a necessary first step for assessing the broader impacts of Street Law programs.

Although this project serves as the premier rigorous analysis of Street Law programs' instructors, it is not without its limitations. For example, there were several other variables (e.g., whether a full-time faculty member directs the Street Law program) that were collected in the survey to test for potential moderating or mediating effects on the dependent variables of interest. The small sample size precludes being able to make any concrete conclusions about significance at this point, but exploratory analysis reveals that a number of these variables may impact the effectiveness of Street Law programs. For example, consider the following preliminary data comparing participants in Street Law programs with a faculty advisor $(n=21)$ versus those without a faculty advisor $(n=14)$. Street Law participants with a faculty advisor showed a higher average change score ${ }^{7}$ for several items of interest:

\footnotetext{
7 Paired samples t-tests to assess mean differences between pre-/post-survey responses were computed for both conditions. The reported means represent the average change between pre-survey and postsurvey for all respondents in each condition.
} 
Table 4 Change Scores on Self-Efficacy Variables by Faculty Advisor Condition

\begin{tabular}{|c|c|c|c|}
\hline Variable & $\begin{array}{l}\text { Directed by } \\
\text { faculty } \\
\text { member? }\end{array}$ & Mean & $\begin{array}{l}\text { Standard } \\
\text { Deviation }\end{array}$ \\
\hline \multirow{2}{*}{$\begin{array}{l}\text { Item 2: Develop positive relationship } \\
\text { with clients }\end{array}$} & Yes & .33 & 1.15 \\
\hline & No & .07 & 1.38 \\
\hline Item 3: Speak to small group of & Yes & .10 & .95 \\
\hline non-lawyers & No & -.14 & 1.35 \\
\hline \multirow{2}{*}{$\begin{array}{l}\text { Item 5: Teach non-lawyers about their } \\
\text { rights }\end{array}$} & Yes & .52 & 1.40 \\
\hline & No & .14 & .95 \\
\hline \multirow{2}{*}{$\begin{array}{l}\text { Item 7: Develop positive relationship } \\
\text { with difficult clients }\end{array}$} & Yes & .62 & 1.36 \\
\hline & No & .00 & 1.41 \\
\hline \multirow{2}{*}{$\begin{array}{l}\text { Item 10: Continue to work with clients } \\
\text { after disruptive experience }\end{array}$} & Yes & .29 & 1.19 \\
\hline & No & -.14 & 1.61 \\
\hline
\end{tabular}

In short, Street Law participants in a program with a faculty director reported a greater increase of confidence for several skills between pre-test and post-test. Thus, further research should explore the potential benefits of having a faculty director for Street Law programs. In fact, other scholars have already begun to argue that "any law school that currently has a student-run or voluntary Street Law Program should seriously consider making it part of its credit-bearing curriculum to ensure that it is effective in its mission and provides a rigorous academic experience" (Montana, 2009). Moreover, building 
Street Law into the curriculum may alter law students' professional trajectory. As argued by law professor Sharon Dolovich, "the law school course catalogue is not just the place where students look to decide what to study next semester"; rather, "[i]t is where future lawyers are exposed to the range of possible practice areas, where they discover interests they did not know they had, and where they begin to imagine their professional lives" (2012, p. 218). As an alumnus aptly stated, participating in a Street Law class during law school

showed me that there are lots of cool and alternative ways to use your J.D., and you don't just have to go straight to some firm in LA and be miserable. It was definitely one of the classes that helped me take a less streamlined approach to my career and what it means to be a lawyer. (UCLA Law alumni, personal communication, February 23, 2018)

Expanding the types of careers law students envision has great value, especially when Street Law instructors could also become a crucial resource for society. As evidenced by the results to RQ6 (Does participation in Street Law impact law students' self-efficacy for developing a variety of soft skills?), Street Law often builds a connection between future lawyers and members of the community. Thus, investment in public interest programs such as Street Law is not only a valuable pedagogical decision but could also lead to a cornucopia of socio-cultural benefits that research projects such as this one only begin to unveil. 
Program evaluation literature consistently recogniszes that real-world constraints limit evaluation efforts (Berk \& Rossi, 1999; Fisher, Laing, Stoeckel, \& Townsend, 1991; Valente, 2002). In other words, any study design will face administrative, fiscal, political, practical, etc. constraints. Thus, the goal is to design and execute the best evaluation possible given the restraints. My program evaluation sought to do just that; these initial findings will serve as the basis for further program evaluations of Street Law and other public law education programs by me, and ideally other scholars as well. But, as we must remember,

there is no fixed recipe. Prescriptions for 'successful' evaluations are, in practice, prescriptions for failure. The techniques that evaluations may bring to bear are only tools, and even the very best of tools does not ensure a worthy product. Just as for any craft, there is no substitute for intelligence, experience, perseverance, and a touch of whimsy. (Berk \& Rossi, 1999, p. 107)

Ultimately, although Street Law is a relatively nascent part of the legal academy, it is a prominent public law education program that serves a potentially crucial role in helping law students prepare to practice. However, evaluations of iterations of this program have employed varied and inconsistent metrics, thereby leaving us with limited understanding about their effectiveness. This project marks the first multimethod empirical, standardised program evaluation of Street Law instructors from law schools across the nation. In addition to completing this program evaluation, the project also (1) 
develops a theoretical framework that will enable law school administrators and scholars from a variety of disciplines to understand how law students are impacted by Street Law programs, and (2) lays the foundation for future assessments of Street Law and other public law education programs. Such assessments should be undertaken with rigor because these programs have broad potential to affect law students' transition to practice and society at large. 


\section{REFERENCES}

Alexander, M. C. (1993). Law-Related Education: Hope for Today's Students. Ohio NUL

Rev., 20, 57.

Araujo, R. J. (1999). The Lawyer's Duty to Promote the Common Good: The Virtuous

Law Student and Teacher. S. Tex. L. Rev., 40, 83.

Arbetman, L. (2018). Street Law, Inc.: Context, History, and Future. International Journal of Public Law, 2(1), 3-27.

Armor, D., Conry-Oseguera, P., Cox, M., King, N., McDonnell, L., Pascal, A., Pauly, E.,

\& Zellman, G. (1976). Analysis of the school preferred reading program in selected Los Angeles minority schools. The Rand Corporation.

Arthurs, S. G. (2015). Street Law: Creating Tomorrow's Citizens Today. Lewis \& Clark

L. Rev., 19, 925.

Arthurs, S., Cooperman, M., Gallagher, J., Grealy, F., Lunney, J., Marrs, R., \& Roe, R. (2017). From Zero to 60: Building Belief, Capacity and Community in Street Law Instructors in One Weekend. International Journal of Clinical Legal Education, 24(2), 118-241.

Ashton, P. T., \& Webb, R. B. (1986). Making a difference: Teachers' sense of efficacy and student achievement. Longman Publishing Group. 
Bandura, A. (1977). Self-efficacy: Toward a Unifying Theory of Behavioral Change. Psychological Review, 84(2), 191-215.

Bandura, A. (1997). Self-efficacy: The exercise of control. New York: Freeman.

Bandura, A. (2006). Guide for Constructing Self-Efficacy Scales. Self-Efficacy Beliefs of

Adolescents, 5, 307-337.

Barkai, J. L., \& Fine, V. O. (1982). Empathy training for lawyers and law students. Sw.

UL Rev., 13, 505.

Berk, R. A., \& Rossi, P. H. (1999). Thinking about program evaluation. Sage.

Binder, D. A., \& Bergman, P. (2003). Taking Lawyering skills training seriously. Clinical L. Rev., 10, 191.

Boccaccini, M. T., Boothby, J. L., \& Brodsky, S. L. (2002). Client-relations skills in effective lawyering: Attitudes of criminal defense attorneys and experienced clients. Law $\mathcal{E}$ Psychol. Rev., 26, 97.

Bouffard-Bouchard, T. (1990). Influence of self-efficacy on performance in a cognitive task. The Journal of Social Psychology, 130(3), 353-363. 
Bureau of Labor Statistics (2020). Labor Force Statistics from the Current Population

Survey. Retrieved from https://www.bls.gov/cps/cpsaat11.htm

Christensen, L. M. (2009). Enhancing Law School Success: A Study of Goal Orientations, Academic Achievement and the Declining Self-Efficacy of Our Law Students. Law $\mathcal{E}$ Psychol. Rev., 33, 57.

Cunningham, C. D. (1998). Evaluating Effective Lawyer-Client Communication: An

International Project Moving from Research to Reform. Fordham L. Rev., 67, 1959.

Diaz, R. J., Glass, C. R., Arnkoff, D. B., \& Tanofsky-Kraff, M. (2001). Cognition, anxiety, and prediction of performance in 1st-year law students. Journal of Educational Psychology, 93(2), 420.

Dolovich, S. (1998). Making Docile Lawyers: An Essay on the Pacification of Law Students. HARV. L. REV., 111, 2027-2041.

Dolovich, S. (2012). Teaching Prison Law. Journal of Legal Education, 62, 218.

Dweck, C. S., \& Leggett, E. L. (1988). A social-cognitive approach to motivation and personality. Psychological review, 95(2), 256.

Elliot, A. J., \& McGregor, H. A. (2001). A $2 \times 2$ achievement goal framework. Journal of personality and social psychology, 80(3), 501. 
Fines, B. G. (1996). Competition and the Curve. UMKc L. REv., 65, 879.

Fisher, A. A., Laing, J. E., Stoeckel, J. E., \& Townsend, J. W. (1991). Handbook for family planning operations research design. New York, NY: Population Council.

Hampton, N. Z. (1998). Sources of Academic Self-Efficacy Scale: An assessment tool for rehabilitation counselors. Rehabilitation Counseling Bulletin.

Kovach, K. K. (1998). The Lawyer as Teacher: The Role of Education in Lawyering. Clinical L. Rev., 4, 359.

Lent, R. W., Brown, S. D., \& Larkin, K. C. (1984). Relation of self-efficacy expectations to academic achievement and persistence. Journal of counseling psychology, 31(3), 356.

Lent, R. W., Sheu, H. B., Singley, D., Schmidt, J. A., Schmidt, L. C., \& Gloster, C. S. (2008). Longitudinal relations of self-efficacy to outcome expectations, interests, and major choice goals in engineering students. Journal of Vocational Behavior, 73(2), 328-335.

MacDougall, C., \& Baum, F. (1997). The devil's advocate: A strategy to avoid groupthink and stimulate discussion in focus groups. Qualitative health research, 7(4), 532-541.

MacDowell, E. L. (2008). Law on the street: Legal narrative and the Street Law classroom. Rutgers Race \& L. Rev., 9, 285.

Madison III, B. V. (2007). The elephant in law school classrooms: Overuse of the Socratic method as an obstacle to teaching modern law students. U. Det. Mercy L. Rev., 85, 293. 
Maughan, C., \& Webb, J. (2005). Lawyering skills and the legal process. Cambridge University Press.

Matsui, T., Matsui, K., \& Ohnishi, R. (1990). Mechanisms underlying math self-efficacy learning of college students. Journal of Vocational Behavior, 37(2), 225-238.

McKinney, R. A. (2002). Depression and anxiety in law students: Are we part of the problem and can we be part of the solution. Legal Writing: J. Legal Writing Inst., 8, 229.

Montana, P. G. (2009). Lessons from the Carnegie and Best Practices Reports: A Look at

St. John's University School of Law's Street Law Program as a Model for Teaching Professional Skills. TM Cooley J. Prac. \& Clinical L., 11, 97.

Multon, K. D., Brown, S. D., \& Lent, R. W. (1991). Relation of self-efficacy beliefs to academic outcomes: A meta-analytic investigation. Journal of counseling psychology, 38(1), 30.

O'Brien, E. L., \& Arbetman, L. P. (1977). New Clinical Curriculum: Teaching Practical Law to High School Students and Inmates, A. J. Legal Educ., 29, 568.

Pajares, F. (1996). Self-efficacy beliefs in academic settings. Review of educational research, 66(4), 543-578. 
Palmer, J. S. (2015). Millennials Are Coming: Improving Self-Efficacy in Law Students through Universal Design in Learning, The. Clev. St. L. Rev., 63, 675.

Pinder, K. A. (1998). Street law: Twenty-five years and counting. JL E Educ., 27, 211.

Protheroe, N. (2008). Teacher Efficacy: What Is It and Does It Matter?. Principal, 87(5), $42-45$.

Roe, R. (2012). Street Law Clinics at Georgetown University Law Center, Washington, D.C., and Others. The Education Pipeline to the Professions: Programs That Work To Increase Diversity. Sarah E. Redfield (ed.). Carolina Academic Press. 135-144.

Rosen, J. A., Glennie, E. J., Dalton, B. W., Lennon, J. M., \& Bozick, R. N. (2010). Noncognitive Skills in the Classroom: New Perspectives on Educational Research. RTI International. Triangle Park, NC.

Schunk, D. H. (1984). Self-efficacy and classroom learning. Psychology in the Schools, 22(2), 208-223.

Schunk, D. H. (1991). Self-efficacy and academic motivation. Educational psychologist, 26(3-4), 207-231.

Schunk, D. H. (1995). Self-efficacy and education and instruction. In J. E. Maddux (Ed.), Self-efficacy, adaptation, and adjustment: Theory, research, and application (pp. 281-303). New York: Plenum. 
Schwartz, M. H. (2003). Teaching law students to be self-regulated learners. L. Rev. MSU-DCL, 447.

Smith, R. H. (2015). From Students to Colleagues: How the Legal Writing Classroom Can Create Conscientious and Empathetic Practitioners. Legal Writing Institute, 10-12.

Sternlight, J. R., \& Robbennolt, J. (2007). Good lawyers should be good psychologists:

Insights for interviewing and counseling clients. Ohio St. J. on Disp. Resol., 23, 437

Tolbert, Anthony. (2018). Street Law -- Youth \& Education [Syllabus]. Los Angeles, CA: UCLA School of Law.

Tschannen-Moran, M., Hoy, A. W., \& Hoy, W. K. (1998). Teacher efficacy: Its meaning and measure. Review of educational research, 68(2), 202-248.

Usher, E. L., \& Pajares, F. (2008). Sources of self-efficacy in school: Critical review of the literature and future directions. Review of educational research, 78(4), 751-796.

Valente, T. W. (2002). Evaluating health promotion programs. Oxford, England: Oxford University Press. 
Zimmerman, B. J. (2000). Self-efficacy: An essential motive to learn. Contemporary educational psychology, 25(1), 82-91. 